"History of the Development of the Lowest Forms of Infusorial Life" was a model of clearness and succinctness; and the President himself paid a compliment to Mr. Bennett's paper, which followed, on the "Theory of Natural Selection looked at from a Mathematical Point of View," as the first attack on the hypothesis conceived in a philosophical spirit, and such a paper as it is the special object of the Association to bring out. The great question of the meeting, that of "Spontaneous Generation," has already occupied sufficient space in our columns; we look to the Liverpool meeting as the starting-point from which the discussion must in future be carried on in a truly philosophical and inductive spirit, free from the dogmatism which has hitherto surrounded it.

The attitude of Liverpool towards the Association has been somewhat of a puzzle to its members. If we were to judge from the remarks heard in the streets and from tl e ordinary visitors at the hotels, and the "intelligent policemen" who were posted here and there to direct the wandering visitor, we might suppose that a meeting of the British Association was a monthly occurrence in Liverpool, so utterly indifferent did they appear to it. The prevalent opinion appeared to be that we were another Church Congress in some sort of disguise. That there is a public in Liverpool who watched its proceedings with intelligence and interest was evident; but this, at least, is certain, that such a public has no representative in the Liverpool press. Let any one who wishes to see what the papers say about the Association take up the Litserpool Courier of this morning, where they will find a leader devoted to a ponderously jocose reply to an innocent remark of ours last week. "Save us from our friends" was the remark with which we laid down the following comment on the Association :- "The philosophers have come and gone, and Liverpool is at peace. They had a week of tremendous talk-tremendous not only as regards volubility, which is a blight we are well accustomed to in Liverpool, but also as regards the technical ponderosity of the themes. However, it is over at last, and though we entertain the most devout admiration for science and scientific people, a sigh of relief escapes involuntarily as we speed the parting guest. It was impossible that we could live long at the high pressure of the past week. It was more than human nature-of course we except scientific human nature, which is on a higher round in the Darwinian ladder than we poor cotton-dealers and traffickers - could bear for another seven days. 'The philosophy was too exalted for our earthy intellects, and we are bound to confess that the local savans-we have quite a battalion of the genus, such as they are-manifested signs of weariness under the tempest-torrent of imported intelligence. Of course it was right that the personages who hang on to the skirts of philosophy should be members of the British Association; but what a change between the first and the last day! Mathematics and biology were a gay pastime in the initial stage, the wise men and the learned ladies were positively vivacious over the germ-theory, and not a few were prepared to enter the lists against any opponent of abiogenesis. But this enthusiasm could not be sustained, for there was no basis of real intelligent interest, and the animation waned as the stream of science still flowed on."

The reporter of the Courier clearly found that he was getting beyond his depth, and wisely absented himself from the sittings during the last few days, or he would have known that the interest showed no signs of abatement. I venture to predict that those Liverpudlians for whom the meeting was not altogether "caviare" have been so well pleased with the success of the meeting that in due time we shall have another invitation to pay the town a visit, when I hope large numbers of those who have now dispersed will again meet.

It will be seen that the annual grant of 6ool. for the purposes of the Kew Observatory has only two more jears to run. We must trust that the additional means thus placed at the disposal of the Council will be applied to purposes directly connected with the real advancement of science, and will not be frittered away in bricks and mortar.

After holding the concluding general meeting which followed that of the general committee, the visitors to the Association rapidly dispersed; a small proportion, however, staying to avail themselves of one or other of the excursions which were arranged for the Thursday. In this respect next year's meeting at Edinburgh will afford a much Jarger scope for the lovers of the picturesque. $B$.

\section{Resolutions of the General Committee}

Applications for Reports and l'esearches not involving Grants of Money

That Prof. R. B. Clifton, Mr. Glaisher, Mr. Huggins, Dr. Matthiessen, Prof, W. Hallows Miller, Dr. Balfour Stewart, Mr. G. Johnstone Stoney, Lieut. -Col. Strange, and Sir J. Whitworth, Bart., be a Comnittee for the purpose of reporting on Metric Standards, in reference to the communication from Prof. Jacobi, appended hereto :-

"The Academy of Sciences of St. Petersburg, observing that the Standard Metric Weights and Measures of the various countries of Europe and of the United States, differ by sensible, though small, quantities from one another, express the opinion that the continuance of these errors would be highly prejudicial to science. They believe that the injurious effects could not be guarded against by private labours, however meritorious, and they have therefore recommended that an international commission be appointed by the countries interested to deal with this matter. They have decided to bring the subject before the Russian Government, and have appointed a Committee of their own body, who have drawn up a careful Report containing valuable suggestions; and they have deputed Prof. Jacobi to lay this Report before the British Association, and to request the Association to take action in reference to it."

That Dr. Anton Dohrn, Prof. Rolleston, and Mr. P. L. Sclater be a committee for the purpose of promoting the foundation of zoological stations in different parts of the world, recognising the foundation of a zoological station at Naples as a decided step in this clirection; that Dr. Anton Dohrn be the Secretary.

That the committee of Section $D$ be requested to draw up a statement of their views upon Physiological Experiments in their various bearings, and that this document be circulated among the members of the Association.

That the said committee be further requested to consider from time to time whether any steps can be taken by them or by the Association, which will tend to reduce to its minimum the suffering entailed by legitimate physioiogical inquiries, or any which will have the effect of employing the infinence of this Association in the discouragement of experiments which are not clearly legitimate on live animals.

Resolution passed by the Committee of Section D (Biology) :

"That the following gentlemen be appointed a Committee for the purpose of carrying out the suggestion on the question of Physiological Experiments made by the General Committee :Professor Rolleston, Professor Lawson, Professor Balfour, Dr. Gangee, Professor M. Foster, Professor Humphry, Professor W. H. Flower, Professor Sanderson, Professor Macalister, and Professor Redfern; that Professor Rolleston be the Secretary, and that they be requested to report to the Committee."

\section{Involving Application to Government}

That Sir R. I. Murchison, Bart, Sir Charles Lyell, Bart, Mr. Findlay, and Admiral Sir John D. Hay be a committee for the purpose of bringing to the notice of the Commissioners of the Admiralty the importance of revising the survey of the west coast of South America, with a view to ascertaining what changes have taken place in the levels since the recent great earthquakes on that coast; that Mr. Clements Markham be the secretary.

That Prof. Jevons, Mr. R. Dudley Baxter, Sir John Bowring, Mr. J. T. Danson, Mr. James Heywood, Dir. W. B. Hodgson, and Prof. Waley be a committee for the purpose of urging upon her Majesty's Government the expediency of arranging and tabulating the results of the approaching census in the three several parts of the United Kingrlom in such a manner as to admit of ready and effective comparison; that Mr. Edmund Macrory be the secretary. 
Synol'sis of GRANTS OF MONEY appropriated to Scientific Purposes by the General Committee at the Liverpool Meeting in September 1870 . The names of the members who would be entitled to call on the General Treasurer for the respective Grants are prefixed:

\section{Kew Observatory}

The Council.-Maintaining the Establishment of kew Observatory

\section{Mathenatics and Fly'sics}

*Brooke, Mr.--British Rainfall

*Thomson, Professor Sir W. - Underground Temperature .

*Tait, Professor.-Thermal Conductivity of Iron and other Metals

*Thomson, Professor Sir W.-Tidal Observations .

*Glaisher, Mr. - Luminous Meteors

Crossley, Mr.-Observations of Lunar Objects.

Herschel, Sir J.--Recomputation of the Gaussian Constants for 1839 .

Stewart, Professor B.-Standard Measures of Electrical Capacity

Hockin, Mr.-Standard Electrodynamometer

Thomson, Professor Sir W. - Standard Potential Gauge

\section{Chemistry}

Williamson, Professor.-Reports of the Progress of Chemistry .

Brown, Professor Crum.-Thermal Equivalents of the Oxides of Chlorine

\section{Giology}

"Lyell, Sir C., Bart.-Kent's-Cavern Exploration . "Duncan, Dr. P. M.-British Fossil Corals

"Symonds, Rev. W. S.--Sedimentary Deposits in the River Onny

* Mitchell, Mr. W. S.-Leaf-beds of the Lower Bagshot series .

Thomson, Mr. James.-Sections of Fossil Corals:

Scott, Mr. R. H.-Mesozoic Deposits of Omenak, North Greenland

Woodward, Mr. H.-British Fossil Crustacea

Busk, Mr.-Fossil Elephants of Malta

$$
\text { Biology }
$$

*Carruthers, Mr.-Fussil Flora of Britain

"Sharpey, Dr.-Physiological Action of Methyl Compounds.

* Sclater, Mr. -Record of the Progress of Zoology.

* Foster, Professor M.-Heat Generated in the Arterialisation of Blood .

Balfour, Professor.-Effect of the Denudation of Timber on the Rainfall in North Britain .

\section{Geography}

Murchison, Sir R. I., Bart,-Exploration of the Country of Moab

Statistics and Economic Scionce.

*Bowring, Sir J. - Metrical Committee.

$$
\begin{array}{lll}
. \quad 25 & 0 & 0 \\
£ 1840 & 0 & 0
\end{array}
$$

\section{SECTIONAL PROCEEDINGS}

Section A.-Mathematical and Physical Science

Abstract of an Investigation of the Matrimatical Theory of Conbined Streants. - Professor W. J. M. Rankine, F.R.S. The object of the investigation of which this is an abstract is to extend to combinations of any number of streams of fuid, whether liquid, vaporous, or gaseous, the principles which have been applied to combinations of two streams by previous authors, and especially by Professor Zeuner, in his treatise entitled "das Locomotiven-Blasrohr" (Zürich, 1863). Several component streams of fluid, each coming through its own supply-tube and nozzle, are led in directions parallel to each other, into one end of cylindrical space called the junction* Re-appointed. chamber, in which they mingle so as to form a resultant stream; and that resultant strean escapes from the other end of the junction chamber through an orifice called the throat. The clynamical principle upon which the motion depends is that of the equaity of impulse and momentum. The aggregate mo. mentum per second of the component streams is found by multiplying the mass of fluid which comes from each nozzle in a second by its yelocity, and adding together the products. The momentum of the resultant stream is the product of the mass of fluicl discharged from the throat in a second, into the velocity at the throat. The difference of these two momenta is equal to the impulse per second exerted in the junction-chamber, which impulse is found by multiplying the area of the throat by the difference between the intensities of the pressure at the nozzle end and at the throat end of the chamber respectively. If there be a gain of momentum, the pressure at the throat is less than at the nozzles; if there be a loss of momentum, the pressure at the throat is greater than at the nozzles.

There is always a loss of energy, which is expended in producing eddies; unless the velocities of the component and resultant streams are all equal to each other. The amount ot that loss can be calculated in any given case, by the help of the principle already stated; and that principle being expressed in the form of an equation, and taken together with another equation expressing the equality of the mass discharged at the throat to the sum of the masses which come through the nozzles, affords the means of solving various problems as to combined streams.

Abstract of a Paper on the Thermo-dynamic Accoleration and Retardation of Streams. - Professor W. J. M. Rankine, F. R.S. * The object of this paper is to state in a more general and comprehensive form than has hitherto been done to my knowledge, a thermo-dynamic and hydro-dynamic principle of which many particular cases are well known and understood. That principle may be stated as follows :-

In a steady stream of any fuid, the abstraction of heat at and near places of minimum pressure, and the addition of heat at and near places of maximunn pressure, tend to procizce acctleration; the addition of heat at and near places of minimum pressure, and the abstraction of heat at and near places of maximum pressure, tend to produce ritardation; in a circulating stream, the quantity of energy of flow gained or lost in each complete circuit is equal to the quantity of encrey lost or suinel in the form of heat: and int the absence of friction, the ratios borme by that quantity to the heat added and the heat abstracted (of which it is the difference) are regulated by the absolute tempirotures at which heat is added and abstracted, agreeably to the second law of thermo-dynamics.

Amongst particular cases of the thermo-dynamic acceleration and retardation of streams, the following may be specified :-

Acceleration by the addition of heat at and near a place of maximum pressure; the draught of a furnace; and the production of disturbances in the atmosphere in regions where the ground is hotter than the air.

Retardation by the abstraction of heat at and near a place of maximum pressure; the dying away of atmospheric disturbances in regions where the ground is colder than the air.

Acceleration by the abstraction of heat at and near a place of minimum pressure ; the injector for feeding boilers, in ; which a jet of stream, being liquefied by the abstraction of heat, is enabled not only to force its way back into the boiler, but to sweep a current of additional water along with it; also, to a certain extent, the ejector-condenser.

The conduction of heat from the parts of a stream where the pressure and temperature are highest, to the parts of the same stream where the pressure and temperature are lowest, produces, according to the foregoing principles, a gradual and permanent retardation of the stream, independently of the agency of friction; and this is accompanied by the production of heat to an amount equivalent to the lost energy of flow.

\section{Section B.-Chemical Science}

On the Weldon Process for the Manufacture of Chlorine.-Mr. W. Weldon, $F \mathbb{C}_{\mathbf{p}} \mathrm{S}$, , the author, said the process was one for the manufacture of chlorine by means of a perpetually-regenerated reagent consisting mainly of a compound containing the elements of peroxide of manganese and lime, and which was previously unknown. He had described the process last year at * Printed in full in the "Philosophical Magazine" for October, 1870. 